JURNFL

INOVRSI EKRNOMI

\section{Factors that affect the performance of the state civil apparatus}

Maryani $^{1}$, Arifani $^{2}$, Djafar $^{3}$

Sekolah Tinggi Ilmu Ekonomi Indonesia Makassar, Indonesia ${ }^{1,2,3}$

Received: 29-09-2021। Revision: 17-10-2021 | Accepted: 23-10-2021

DOI: https://doi.org/10.22219/jiko.v6i03.18277

\begin{abstract}
This study explains the influence and causal relationship between exogenous and endogenous variables based on the research framework. The population in this study is the employees of the Regional Secretariat of the Provinces of South Sulawesi and West Sulawesi, with a total of 40 respondents who are used as research samples, and the analysis was performed by multiple linear regression. This study found that education and training, organizational culture, facilities and infrastructure, and regulations simultaneously significantly influence financial management performance.
\end{abstract}

Keywords: Education and training; organizational culture; facilities and infrastructure; regulations; financial management; state civil apparatus

\footnotetext{
${ }^{1}$ maryaniminhadj@gmail.com
} 


\section{Introduction}

The paradigm of decentralization and regional autonomy transfers the authority that has been in the hands of the Central Government to the Autonomous Regional Government (Provincial and Regency/City). With this authority, autonomous regions will be increasingly demanded and challenged to be creative in developing their autonomous capacity, both institutionally and socio-economically. The enactment of the Regional Autonomy Law, which consists of Law number 22 of 1999 and Law number 25 of 1999 until the issuance of Law 32 and Law 33 of 2004, has given local governments the flexibility to regulate their households. This flexibility is the implementation of Regional Autonomy to improve democracy and regional performance to improve people's welfare towards civil society. The regional performance, which is the goal of implementing regional autonomy, embodies Good Governance in regional government organizations.

The implementation of regional autonomy will, of course, also impact more excellent financing to carry out various programs and activities, which will require administrative arrangements in the field of financial management as a whole. The determination of the flexibility in managing financial administration has been regulated in Government Regulation Number 105 of 2000 concerning Regional Financial Management and Accountability, as well as referring to the Decree of the Minister of Home Affairs number 29 of 2002 concerning Guidelines for Management, Accountability, and Supervision of Regional Finances as well as Procedures for the preparation of the Revenue Budget. and Regional Expenditures, Implementation of Regional Financial Administration and Preparation of Calculations of Regional Revenue and Expenditure Budgets.

The flexibility given requires Regional Financial Management Arrangements that can support the needs of Accountability and Transparency. As one of the areas that culturally and even historically has the fundamental values of government and development activities that have become examples in the development of similar activities in other regions, West Sulawesi Province has institutionally improved itself in carrying out government functions and development and improving services.

The performance approach is structured to overcome the various weaknesses in traditional budgets, especially weaknesses caused by the absence of benchmarks that can measure performance in achieving public service goals and objectives. Budgeting with a performance approach emphasizes the concept of value for money and monitoring of output performance. This approach also prioritizes the mechanism for determining and prioritizing goals and a systematic and rational approach in the decision-making process. Therefore the budget is used as a measuring tool to achieve goals. 
With this challenging task, it must be balanced with an increase in the excellent performance of all employees within the Regional Government of West Sulawesi Province, especially within the Regional Secretariat of West Sulawesi Province, which recently has intensely felt a decline in performance, with indicators that there are still revisions to the concept of ABPD Preparation, Changes, APBD Calculations, Financial Management in general and sometimes the ratification of the APBD into Regional Regulations is still delayed, besides that it is also necessary to improve the performance of financial managers starting from the preparation of the Work Unit Budget Plan proposed by the work unit holding the budget to be included in the annual planning in the form of Regional Revenue and Expenditure Budget, as well as the skills and knowledge of employees through education and training, especially those who manage Regional Finances and must be supported by adequate facilities and infrastructure which will be adjusted to the applicable laws and regulations in the field of financial management and applicable operational policies.

Another weakness is the problem of consistency in the determination and enforcement of several laws and regulations in regional financial management, which should be the basis and legal reference that binds in general to improve the performance of financial managers. However, the inconsistent stipulation and enforcement of several laws and regulations in financial management will lead to unclear which rules should be used as a reference in financial management, especially at the regional secretariat of West Sulawesi Province.

Performance is work achievement, which compares work results and established standards (Dessler, 2015). Performance is the result of work in quality and quantity achieved by a person carrying out tasks according to the responsibilities given (Sapiatri, 2016). Meanwhile, Hermawati's (2014) understanding of performance links work results with behavior. As a behavior, performance is a human activity directed at carrying out organizational tasks assigned to it. The fundamental question is, does the regulation affect the performance of the state civil apparatus, especially in the financial sector? We also add three exogenous variables that affect performance; the details of the model we built are in Fig. 1.

\section{Method}

The implementation of this research was carried out at the Regional Secretariat of the Provinces of South Sulawesi and West Sulawesi for approximately two months, starting from February to April 2021. Sources of data obtained in this study came from respondents through questionnaires with a sample of 40 respondents. The method of analysis carried out in this study was quantitative 
analysis, using multiple linear regression analysis with a regression model according to the model in Fig.1.

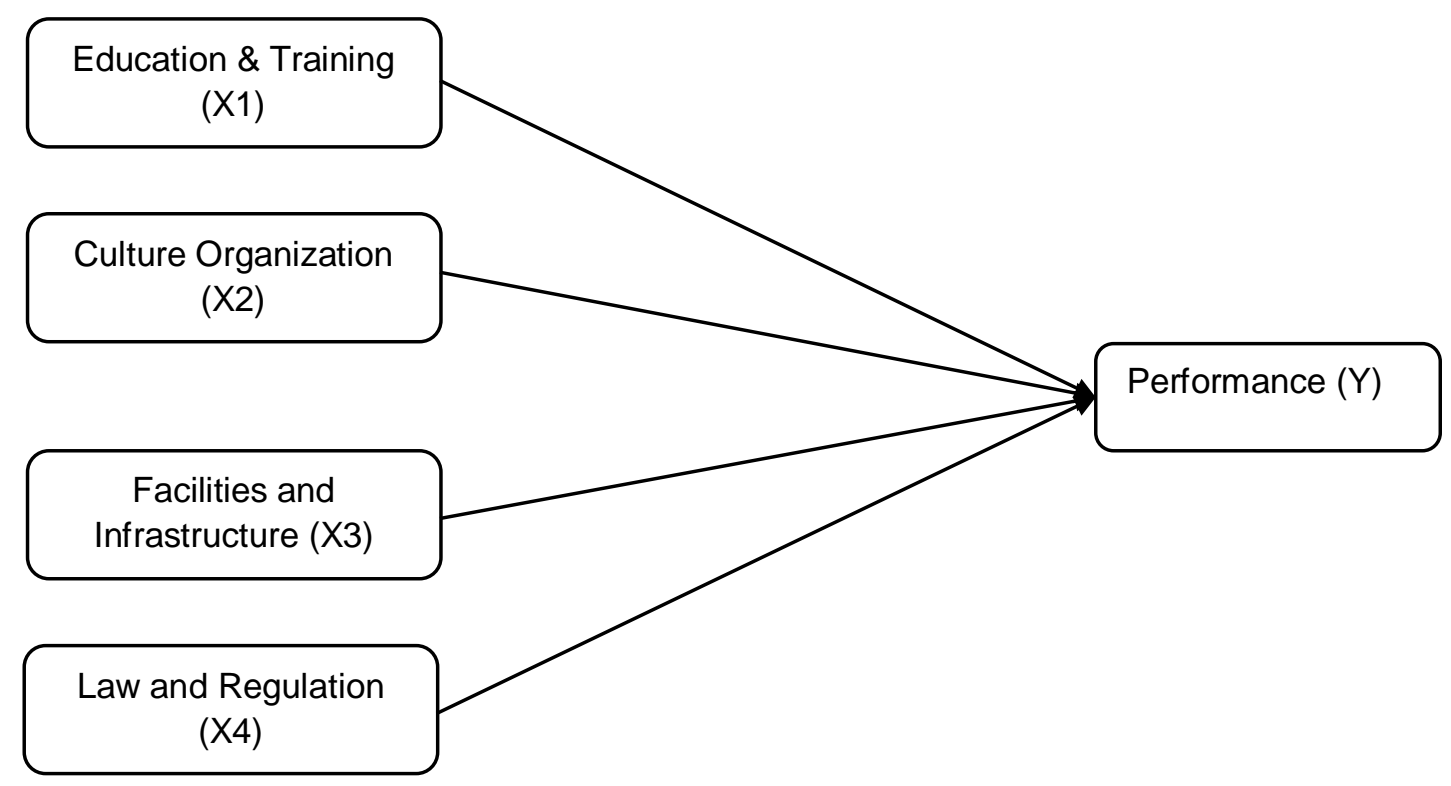

Figure 1. Research Framework

\section{Empirical Result}

Base on Table 1, the result shows that these variables have a significant influence in line with the opinion of Flippo (1992), which states that education and training of employees are needed to create maximum performance because the main goal is a specific increase in skills and knowledge to carry out a particular job. Stoner (1996) says that organizational culture is a framework that guides daily behavior and decision-making for employees and directs their actions to achieve organizational goals. It is further stated that organizational culture must align with organizational actions such as planning, organizing, leading, and controlling. Djailani (2015) says that pleasant working conditions, characterized by adequate facilities and infrastructure, especially during working hours, will improve employee morale and work earnestness. Good work equipment such as computers, desks and chairs, comfortable workspaces, protection against hazards, good air circulation, adequate lighting, and cleanliness will not only increase work enthusiasm but can also increase work enthusiasm and productivity.

In addition, because the results of this study also show that regulations and laws and regulations also have a positive influence on performance, we believe that measurable, efficient, and non-overlapping regulations will be beneficial for optimizing the performance of state civil servants not only in the financial sector but also other fields. 
Table 1. Results of multiple linear regression analysis

\begin{tabular}{lcc}
\hline \multicolumn{1}{c}{ Variable } & Coefficient Regression & Sig. \\
\hline Education \& Training (X1) & 0.483 & 0.001 \\
Culture Organization (X2) & 0.236 & 0.041 \\
Facilities and Infrastructure (X3) & 0.493 & 0.012 \\
Law and Regulation(X4) & 0.408 & 0.034 \\
Constant & -4.894 & 0.000 \\
\hline R-square & 0.887 & \\
\hline Sig. F test & 0.003 & \\
\hline
\end{tabular}

\section{Conclusions}

Based on the results of the analysis and discussion that has been carried out, it can be concluded several things as follows: Education and training (X1), organizational culture (X2), facilities and infrastructure (X3), and laws and regulations (X4) together have a significant influence on the performance of the financial management apparatus at the Provincial Secretariat of South and West Sulawesi Province. We also argue that optimization work performance can drive with efficient and nonoverlapping law and regulation. The proper law and regulation will decrease the burden of other exogenous variables such as education, organizational culture, and facility.

\section{References}

Dessler, Gary. (2015). Manajemen Sumber Daya Manusia. Edisi 14. Jakarta: Salemba.

Djailani, A. R. (2015). Strategi Manajemen Sumber Daya Manusia STKIP Muhammadiyah Aceh Tengah. Jurnal Administrasi Pendidikan: Program Pascasarjana Unsyiah, 3(2).

Edwin B. Flippo. (1992). Manajemen Personalia, Mc Hill Book Company, Singapura.

Hermawati, A., Anam, C. ., \& Suhermin, S. (2020). Determining Strategy to Improve Human Resources Performance by Identifying Tourism Condition SMEs. Academic Journal of Interdisciplinary Studies, 9(6), 228. https://doi.org/10.36941/ajis-2020-0127

Sapiatri, Ranty (2016). Pengaruh Komitmen Organisasi Terhadap Kinerja Karyawan Perusahaan Listrik Negara Area Pekanbaru. JOM Fisip Vol. 3 No. 2 - Oktober 2016, pp. 1-9.

Stoner, James AF. (2001). Management. Jilid II. Penterjemah Agus Maulana Dkk. CV. Erlangga. Jakarta. 
